\title{
Nutritional Evaluation, Antioxidant, Anticancer and Antimicrobial Activities of Egyptian amhat date palm fruit
}

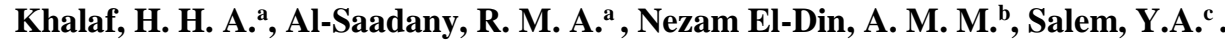 \\ aFood Technology Dept., Fac. of Agric.,Benha University, Egypt. \\ ${ }^{\mathrm{b}}$ Food Technology Research Institute, Agricultural Research Center, Giza, Egypt. \\ ${ }^{\mathrm{c}}$ Central Laboratory for Date Palm Research and Development.
}

Corresponding author: Yathrebsalem75@yahoo.com

\begin{abstract}
Amhat date (soft variety) is one of popular fruit in Egypt. The varieties in Egypt were soft, semi dry and dry, most of Egypt's production of dates is soft, amhat date variety in Egypt is consumed in rutab stage. Therefore, it was necessary to be ripened artificially to increase the shelf life and prevent its unacceptable taste. So, the chemical composition of amhat date were estimated (moisture, total soluble solids, crude protein, fats, crude fiber). Also, its minerals content were estimated, and the nutritional values of amhat date palm ( khalal, natural rutab and artificial rutab ) were measured. The bioactive compounds were estimated ( total phenolic compounds, simple phenols, total tannins, hydrolysable tannins and condensed tannins ) fractionated phenolic compounds and flavonoids by HPLC ( High Performance Liquid Chromatography )were used for measuring the responsible phenolic compounds of anticancer ( caffeine, p-coumaric acid and ferulic acid ) So, the bioactine compounds have important role of khalal amhat date, natural rutab and artificial rutab amhat date as antioxidant , anticancer and antimicrobial agents.
\end{abstract}

Key words: Amhat date - Chemical composition- phenolic compounds - flavonoid compound - anticancer activity - antimicrobial activity.

\section{Introduction}

The total world production of dates is 8460443 tons and Egypt produced 1694813 tons of dates (FAO, 2016). Egyptian dates represent more than 70 $\%$ soft dates and one of important soft date is Amhat date variety which represent 29193 tons (A.A.C.S. 2016).

The chemical analysis of this variety in khalal stage was $70.0 \%$ for its moisture content and 4.5 for $\mathrm{pH}$ value and the total acidity, reducing sugar, total sugar and total free phenolic compounds were 0.56 , 35.06, 66.4 and $3.00 \%$ (on DW) of Amhat date of khalal stage. While the rutab stage content $50.05 \%$ moisture and $\mathrm{pH}$ value was 5.5 also contained 0.042 , $70.50,71.30,2.12$ and $1.10 \%$ of total acidity, reducing sugar, total sugar, total free amino acid and total free phenolic compound respectively . as reported by (Nezam El.Din and Abd ELHameed,2003).

Abo Taleb et al. (2018) reported that the chemical composition of rutab amhat date was as follows: the moisture was $99.73 \%$, protein was $1.5 \%$ , fat $1.3 \%$, total soluble solid $28.65 \%$, PH value $6.76 \%$, total acidity was $0.190 \%$ and Ash content was $1.84 \%$ (on DW). And they observed that Amhat dates had the highest amount of fructose glucose , mannose and galactose $(41.45,32.32,17.68,17.03 \%)$ respectively. But had the least amount of sucrose was $0.189 \%$ by using HPLC for sugar analysis. Also, they found that the mineral content of fresh amhat dates were Potassium (K) was $370.12 \mathrm{mg} / 100 \mathrm{~g}$, Magnesium (Mg) was $91.756 \mathrm{mg} / 100 \mathrm{~g}$, calcium (Ca) was $157.56 \mathrm{mg} / 100 \mathrm{~g}$, Magnesium $(\mathrm{Mg})$ was
$0.70 \mathrm{mg} / 100 \mathrm{~g}$, Iron $(\mathrm{Fe})$ was $0.721 \mathrm{mg} / 100 \mathrm{~g}$ and zinc $(\mathrm{Zn})$ was $0.309 \mathrm{mg} / 100 \mathrm{~g}$.

The bioactive compounds which are found in some food played good roles as antioxidant, anticancer and antimicrobial, Some of these compounds are phenolic compounds, flavonoids ,tannins, anthocyanidin (Seeram et al.,2005 and Du et al.,2012). Previous components are found in some popular Egyptian food such as date palm fruit .

Date palm fruit is rich by tannins and phenolic compounds especially green and yellow of date fruit ( Pheonix dactylifera L.) . The previous compounds showed clear changes during ripening especially in soft dates from khalal to Rutab stages ( Nezam ElDin and Abd El- Hameed.,2003) .

Abo Taleb et al., (2018) fractionated the amount of individual phenolic acids present of fresh Amhat date by HPLC. And they found that Gallic acid was $5.872 \mathrm{mg} / 100 \mathrm{~g}$ Ellagic acid was $6.075 \mathrm{mg} / 100 \mathrm{~g}$ and the highest amount was e-vinillic acid 50.68 $\mathrm{mg} / 100 \mathrm{~g}$ on dry weight basis. And they also found the quantities of flavonoids compounds were fractionated by HPLC. Were Rutin was 4.382 $\mathrm{mg} / 100 \mathrm{~g}$, Naringin was 1.247 , Quercitrin was 1.991 $\mathrm{mg} / 100 \mathrm{~g}$, Quercetin was $0.509 \mathrm{mg} / 100 \mathrm{~g}$ and the highest amount was Acacetin $10.82 \mathrm{mg} / 100 \mathrm{~g}$.

Benmeddour et al., (2012) studied that the identification and quantification of flavonoids compounds by HPLC (High Performance Liquid Chromatography) and observed that the iso quercetin was $3.03 \mathrm{mg} / 100 \mathrm{~g}$ DW in Ghazi varity and rutin was $2.78 \mathrm{mg} / 100 \mathrm{~g}$ DW in Sebt Mira varity .

The tannin content of different in UAE date palm fruit (Bushibal, Gash Gaafar, Gash Habash, lulu and 
shahla) in different stage (khalal and Rutab) were $1.3,0.9,1.4,0.9,1.6,1.2,1.2,0.8,1.3 \% \mathrm{DW})$ respectively as observed by Al-Hooti et al., (1997).

Abo Taleb et al., (2018) found that the antioxidant activity of amhat dates was $63.3 \%$ (on dry weight basis).

The methanolic extract of Ajwa date inhibit human breast Adenocarcinoma (MCF7) they found that a decrease in cell number at $20 \mathrm{mg} / \mathrm{ml}$ concentration for 48 hour and $72 \mathrm{~h}$. were ranged from $78.20 \%$ to $96 \%$ respectively and at $25 \mathrm{mg} / \mathrm{ml}$ concentration for $72 \mathrm{~h}$ was $99.12 \%$ as reported by Khan et al.,(2016).

Saleh and Otaibi (2013) observed that ethanolic extract of three date palm varieties (Sheshi, khulase and Rezaz). And they found that in Biser stage had the strongest Antimicrobial activity by Staphylococcus saprophyticus (the diameter of inhibition zone 30,35 and $37.5 \mathrm{~mm}$ ) respectively.

So, this study aims to evaluate the nutritive values date fruit (amhat variety) at Khalal stage and Rutab stage. Studing the effect of this food as antioxidant, anticancer and antimicrobial agents.

\section{Material and Methods}

\section{Materials}

Amhat dates variety (phoenix dactylifera $L$.) at Khalal and Rutab stage were obtained from The Central Laboratory for Date palm Research and Development, Agriculture Research Center, Giza , Egypt.

-Chemicals

The chemicals were purchased from ElGomhoria Company for medical materials, Cairo, Egypt.

\section{Methods}

- Technological Methods

Amhat date palm fruit ( ripening operation )

Amhat dates ( in khalal stage ) were stored in freezing condition

At $-18^{\circ} \mathrm{C}$ for one week, then transferred to oven at $40 \circ \mathrm{C}$ for two $\mathrm{h}$. the temperature was increased to $65^{\circ} \mathrm{C}$ for another two h. the moisture content would be in the range from $50.48 \%$ ( rutab stage ).( Nezam El-Din and Abd El- Hameed.,2003) .

Analytical methods -

1-Determination of chemical composition

Moisture content, crude protein, crude fiber, ash content, fats, total acidity ( as citric acid ) and $\mathrm{pH}$ values were determined according to the methods of A.O.A.C.( 2016 ).

\section{2-Determine total soluble solids}

The T.S.S were estimated by using an Atago digital refractometer at $25^{\circ} \mathrm{C}$ ( Ranganna., 2007).

3-Identification and quantification of sugars by HPLC
The samples were fractionated and identified by HPLC "High Performance Liquid Chromatography " (column used was Phenomenex@Luna NH2 250× $4.6 \mathrm{~mm}$, mobile phase was Acetonitrile : HPLC grade water 80:20 ( v/v ), detector by RI detector and data integration by claritychrom@ software , (Food Safety and Quality control Lab., Fac.of Agric. Cairo Univ. ) (HPLC smart line, Knauer, Germany ) according to the method of (Chinnici et al., 2005).

\section{4-Determine minerals content}

Minerals content were determined using atomic absorption spectroscopy as reported by A.O.A.C. (2016).

\section{5-Determine total free phenolic compounds}

Total free phenolic compounds were determined colorimetrically by Folin - Ciocalteu reagent according to spectrophometric method described by (Stratil et al., 2006 ) .

\section{6-Detemination of tannins}

Tannins were estimated according to the method described by Rebaya et al .,(2014).

Tannins fractions (LMWT and HMWT) were determined by this method that reported by Czochanska et al ., (1979).

Condensed tannins were estimated by this method that reported by

(Iqbal et al., 2011)

\section{7-Determine Pigments}

Determination browning content

One gram of samples on dry matter were extracted by ethanol $(60 \%)$

The color of clear extract measured to $420 \mathrm{~nm}$ as reported by Ranganna, (2007).

8-Determination of DPPH free radical scavenging activity (1,1-Diphenyl -2- Picrylhydrazyl ) .

The antioxidant activity of sample extract was estimated in terms of hydrogen donating or radical-scavenging ability using the stable DPPH method as found by" Xu and Chang ., 2007 " The reaction mixture containing $1 \mathrm{ml}$ of extract at concentration $(150 \mu \mathrm{g} / \mathrm{ml})+1 \mathrm{ml}$ DPPH $(0.2 \mathrm{mM})$ was vigorously shaken and incubated in darkness at room temperature for 30 minutes .The absorbance was browse at $517 \mathrm{~nm}$ exploitation UV-visible photometer. Radical scavenging activity was expressed as percent of inhibition and was calculated exploitation the subsequent formula:

\%DPPH $=$ [Absorbance of Control - Absorbance of Sample / Absorbance of Control ] × 100 .

9-Identification and quantification of phenolic and flavonoid compounds by HPLC

Fractionation and identification of phenolic compounds were carried out by HPLC ( Agilent 1260 infinity HPLC series( Agilent USA ), equipped with Quaternary pump, akinetex® $5 \mu \mathrm{m}$ EVO C18 $100 \mathrm{~mm} \times 4.6 \mathrm{~mm}$, (Phenomenex, USA ), the 
separation is achieved using a ternary linear elution gradient with (A) HPLC grade water $0.2 \% \quad \mathrm{H}_{3} \mathrm{PO}_{4}$ $(\mathrm{v} / \mathrm{v})$, (B) methanol and (C) acetonitrile. The injected volume was $20 \mu \mathrm{l}$. Detection VWD detector set at $284 \mathrm{~nm}$. (Food Safety and Quality control Lab., Fac.of Agric. Cairo Univ. ) according to the method described by Pascale et al. (1999), while flavonoid compounds were carried out by HPLC (Aglilent 1260 infinity HPLC Series (Agilent, USA) equipped with Quaternary pump, a Zorbax Eclipe plus C18 column $150 \mathrm{~mm} \times 4.6 \mathrm{~mm}$ id., (Aglient technologies , USA ) Eluent : methanol : $\mathrm{H}_{2} \mathrm{O}$ with $0.5 \% \mathrm{H}_{3} \mathrm{PO}_{4}, 50: 50$ with flow rate $1 \mathrm{ml} / \mathrm{min}$. the injected volume was $20 \mu 1$. Detection ; UV detector set at $272 \mathrm{~nm}$ ) (Food Safety and Quality control Lab., Fac.of Agric. Cairo Univ. ) according to the method described by Pirjo et al. (2000).

\section{0-Biological Evaluation \\ Cytotoxic activity as anticancer \\ -Preparation of sample extracts}

50 gram of dry matter of sample( date palm fruit) was extracted by suitable solvent ( ethanol, methanol, and acetone ). The extract was filtered and evaporated by rotary evaporator at $45^{\circ} \mathrm{C}$. The extract was stored at $-18^{\circ} \mathrm{C}$ until using measurement of cytotoxicity for anticancer by SRB assay "Sulforhodamine B Colorimetric assay" It was used method method of" Skehan et al., 1990" for determination of potential cytotoxicity.

Cells were coated in 96-multiwell plate $\left(10^{4}\right.$ cells/well) for 24 hours before treatment with compounds or sample to allow attachment of cell to the wall of plate. Different concentration of the compounds or sample under test $(0.0,62.5,125$, $500 \mu \mathrm{g} / \mathrm{ml}$ ) were added to cell monolayer. Triplicate wells were prepared for each individual dose. Monolayer cells were incubated with the compounds in atmosphere of 5\% carbon dioxide for 48 hours at $37{ }^{\circ} \mathrm{C}$. Cells were fixed, washed and strained with sulfo-rhodamine-B stain after 48 hours. Excess stain was washed with $1 \%$ acetic acid and attached stain was recovered with Tris-EDTA buffer, an ELISA reader was used to measure color intensity by photometric determination of absorbance at $570 \mathrm{~nm}$ using microplate ELISA. Triplicate repeats were performed for each concentration and the average was calculated. Data were expressed as the percentage of relative viability compared with the untreated cells and the vehicle control, with cytotoxic indicated by $<100$ relative viability.

Percentage of relative viability was calculated using the following equation:

(Absorbance of treated cells/ Absorbance of control cells $) \times \mathbf{1 0 0}$

Then the half maximal inhibitory concentration $\left(\mathrm{IC}_{50}\right)$ was calculated from the equation of the dose response curve. (Skehan et al., 1990 ) ."This experiment was conducted at the Egyptian Cancer Institute, Cairo, Egypt".

\section{1-Measurement of antimicrobial activity \\ -Preparation of sample extracts}

The samples "equal to 50 gram dry matter " was extracted by $100 \mathrm{ml}$ aceton "70 \%". Each extract was filtered and concentration by rotary evaporator at 25 $\circ \mathrm{C}$. The extract kept at $-18^{\circ} \mathrm{C}$ until use (Daoud $\boldsymbol{e t}$ al., 2015 ).

The extract was tested against" two Gram positive bacteria" Staphylococcus aureus , Bacillus subtilis and" Gram negative bacteria " Escherichia coli, Salmonella typhi. The anti-fungal of the compounds were tested against fungus "Aspergillus flavus ".

Paper discs of Whatman filter paper were prepared with standard size $(3 \mathrm{~mm})$.And they were cut and sterilized in an autoclave. The extract solutions were added using micropipette 100,200 and $400 \mu 1$, the concentration of date palm fruit were $0.125,0.25$ and $0.5 \mathrm{mg}$ respectively . Previous volumes of extracts were added to the filter paper which was placed in middle of petri dishes contained nutrient agar media with individual microorganisms Staphylococcus aureus, Bacillus subtilis , Escherichia coli, Salmonella typhi, Aspergillus flavus )The petri dishes were brooded at $36^{\circ} \mathrm{C}$ and the inhibition zones were recorded after $24 \mathrm{hrs}$. Each treatment was replicated three times. Ampicilin ( 1 $\mathrm{mg} / \mathrm{ml}$ ) was individually used as positive controls for bacteria and Clotrimazole was individually used as positive controls for fungi, antimicrobial activity was determined according to the method described by Fadda and Hala ( 2013 ) at Food Technology Research Institute , Agric. Res. Center, Giza , Egypt - The $\%$ activity index for the compounds was calculated by:

$\%$ Activity

$=\frac{\text { Zone of inhibition by test compound }(\text { diametre })}{\text { Zone of inhibition of } \text { standard }(\text { diametre })} \times 100$

\section{2-Sensory evalution}

Amhat date fruit samples were organoleptically tested for their colour, taste, odour, texture and general appearance using scale from 1 to 10 , panel test was done in Food Technology Research Institute. (Barrett et al., 2010 ) .

\section{Statistical Analysis}

Data analysed with SPSS (Statistical Package for the Social Science) 20.0 for windows. The mean, SD of mean and LSD were calculated. The Data were analysed by one- way analysis of variance (ANOVA) . Duncan's multiple range test was used to separate means. Significance was accepted at a probability $\mathrm{P}$ $\leq 0.05$. 
Results and Discussion

The physiochemical characteristics of amhat date palm fruit.

Data represent in Table (1) showed the physicochemical of amhat dates at khalal stage , natural and artificial rutab stage .It could noticed that the moisture content of khalal date was $72.06 \%$ which decreased by ripening to $55.39 \%$ and $50.48 \%$ of natural rutab and artificial rutab of amhat date respectively. The $\mathrm{pH}$ value of khalal amhat date was 4.5 which increased to 5.5 and 5.7 of natural and artificial ripening respectively. Total acidity of khalal Amhat date was $0.56 \%$ which changed to $0.45 \%$ and $0.42 \%$ of natural and artificial rutab dates .
Crude protein of amhat date were $1.53,1.57$ and $1.61 \%$ of khalal, natural and artificial ripening dates respectively that is due to loss moisture Nasir et al., ( 2014 ).

Crud fiber of khalal amhat date was $14.46 \%$ which decreased to $9.84 \%$ and $9.59 \%$ of khalal, natural and artificial ripening dates respectively. Lipid content of amhat dates were $0.38,0.36$ and $0.36 \%$ of khalal, natural and artificial ripening dates respectively Al- Hooti et al. , ( 1997 ) .

Ash content of khalal amhat date was $1.88 \%$ which increased to $1.92 \%$ and $2.05 \%$ of natural and artificial ripening respectively.

Table 1. Physiochemical characteristics of khalal Amhat date, natural rutab and artificial rutab Amhat date .

\begin{tabular}{lcccc}
\hline Samples Items & Khalal & N. rutab & A. rutab & LSD \\
\hline Moisture \% & $72.06 \pm 1.80^{\mathrm{a}}$ & $55.39 \pm 1.38^{\mathrm{b}}$ & $50.48 \pm 1.26^{\mathrm{c}}$ & $2.998^{0.05}$ \\
Total solid T.S.\% & $27.94 \pm 0.70^{\mathrm{c}}$ & $44.61 \pm 1.12^{\mathrm{b}}$ & $49.52 \pm 1.24^{\mathrm{a}}$ & $2.084^{0.05}$ \\
pH value & $4.5 \pm 0.11^{\mathrm{b}}$ & $5.5 \pm 0.14^{\mathrm{a}}$ & $5.7 \pm 0.14^{\mathrm{a}}$ & $0.263^{0.05}$ \\
Total Acidity \% & $0.56 \pm 0.014^{\mathrm{a}}$ & $0.45 \pm 0.011^{\mathrm{b}}$ & $0.42 \pm 0.011^{\mathrm{c}}$ & $0.024^{0.05}$ \\
Crude protein \% & $1.53 \pm 0.038^{\mathrm{b}}$ & $1.57 \pm 0.039^{\mathrm{ab}}$ & $1.61 \pm 0.04^{\mathrm{a}}$ & $0.078^{0.05}$ \\
Crude fiber \% & $14.46 \pm 0.36^{\mathrm{a}}$ & $9.84 \pm 0.25^{\mathrm{b}}$ & $9.59 \pm 0.24^{\mathrm{b}}$ & $0.575^{0.05}$ \\
Total lipid \% & $0.38 \pm 0.01^{\mathrm{a}}$ & $0.36 \pm 0.009^{\mathrm{b}}$ & $0.36 \pm 0.009^{\mathrm{b}}$ & $0.018^{0.05}$ \\
Total soluble solid \%( T.S.S.) & $21 \pm 0.53^{\mathrm{c}}$ & $35 \pm 0.88^{\mathrm{b}}$ & $41 \pm 1.03^{\mathrm{a}}$ & $1.668^{0.05}$ \\
Ash \% & $1.88 \pm 0.047^{\mathrm{b}}$ & $1.92 \pm 0.048^{\mathrm{b}}$ & $2.05 \pm 0.05^{\mathrm{a}}$ & $0.098^{0.05}$ \\
\hline
\end{tabular}

*All chemical composition measured on dry weight basis (DWB) except total soluble solids and total solids which measured on fresh weight basis (FWB).* The mean value with different superscript alphabets in rows indicate significantly differences $(\mathrm{p} \leq 0.05)$ using LSD TEST

2. Fractionation of sugars content of Amhate date ( khalal, Natural rutab and Artificial rutab using HPLC ( High Performance Liquid Chromatography )

Sugars content of amhate date variety by using HPLC for measuring the sugars content of Amhate date it was found that khalal, N. rutab and A. rutab contained $21.95,30.03$ and $31.12 \% ; 24.79,32.33$ and $35.76 \%$; and $0.61,2.13$ and $1.67 \%$ ( DW ) of fructose, glucose and sucrose respectively ( Table 2) - So, The high content of fructose and glucose after ripening to rutab may be related to release of sugars from hydrolysable tannins and saponin by hydrolysis.as reported by (Adeosun et al., 2016 )

Table 2. Sugars fractionation by HPLC of Amhate date ( Khalal, N. rutab and A. rutab )

\begin{tabular}{rcccc}
\hline \multicolumn{1}{c}{ Samples } & Khalal & N. rutab & A. rutab \\
\hline Fructose\% & 21.95 & 30.03 & 31.12 \\
Glucose \% & 24.79 & 32.33 & 35.76 \\
Sucrose \% & 0.61 & 2.13 & 1.67 \\
\hline
\end{tabular}

*The percentage measured on dry weight basis .

3.Minerals content of khalal amhat date, natural and artificial rutab amhat date.

The minerals content of khalal amhat date, natural and artificial rutab amhat dates ( Table 3 ) showed the micro and macro - element of amhat dates the iron( $\mathrm{Fe}$ of khalal amhat date was $2.11 \mathrm{mg} / 100 \mathrm{~g}$ which increased in nutral rutab amhat date and artificial amhat date were 2.22 and 2.39 $\mathrm{mg} / 100 \mathrm{~g}$ respectively .

Also Phosphorus (P) was increased by ripening, at khalal stage phosphorus was $110 \mathrm{mg} / 100 \mathrm{~g}$, in natural and artificial rutab were 120 and 132.61 $\mathrm{mg} / 100 \mathrm{~g}$ respectively.
Potassium, calcium and magnesium were decreased by ripening, Potassium content ( $\mathrm{K}$ ) of amhat date at khalal stage, natural and artificial rutab were 440,433 and $430 \mathrm{mg} / 100 \mathrm{~g}$ respectively . calcium of khalal amhat date was 460 $\mathrm{mg} / 100$, natural and artificial rutab amhat date were 380 and $371.85 \mathrm{mg} / 100 \mathrm{~g}$ respectively. Magnesium of khalal amhat date was $270 \mathrm{mg} / 100 \mathrm{~g}$ , natural and artificial rutab amhat date were 230 $\mathrm{mg} / 100 \mathrm{~g}$ and $231.90 \mathrm{mg} / 100 \mathrm{~g}$ respectively. These results were agreement with Al-Hooti et al., (1997). 
Table 3. Minerals content (mg $/ 100 \mathrm{~g}$ ) of khalal amhat date, natural and artificial rutab amhat date (on dry weight basis)

\begin{tabular}{lccccc}
\hline $\begin{array}{c}\text { Minerals } \\
\text { Samples }\end{array}$ & $\mathrm{Fe}$ & $\mathrm{P}$ & $\mathrm{K}$ & $\mathrm{Ca}$ & $\mathrm{Mg}$ \\
\hline $\begin{array}{l}\text { Khalal Amhat } \\
\text { date }\end{array}$ & 2.11 & 110 & 440 & 460 & 270 \\
Natural rutab & 2.22 & 120 & 433 & 380 & 230 \\
Artificial rutab & 2.39 & 132.61 & 430 & 371.85 & 231.90 \\
\hline
\end{tabular}

\section{Phenolic compounds of amhat date.}

From Table (4) it was cleared that total phenolic compounds of khalal amhat dates were $2.86 \%$ which decreased by natural ripening (rutab) to $1.524 \%$ and by artificial ripening to $1.817 \%$. The decrease of total phenolic compounds may be related to enzymatic browning by polyphenol oxidase as found by Parr and Bolwell ( 2000 ) . So high significant difference between total phenolic compound of khalal amhate date and the others rutab dates.

Simple phenolic compounds of khalal dates were $1.330 \%$ but Simple phenolic compounds after natural ripening of amhat date was $1.318 \%$ and after artificial ripening of amhat date was $0.640 \%$ the clear decrease after artificial ripening may be related to the effect low heating on acceleration of enzymatic and non- enzymatic browning . A significant difference of simple phenols was found between khalal amhate date and artificial repining.

Hydrolysable tannin of khalal date was $1.370 \%$ but for natural rutab was $0.950 \%$ and artificial rutab was $1.160 \%$. The increase of artificial rutab than natural rutab resulted from the effect of heat during ripening by oven on inhibition of enzymatic hydrolysis of hydrolysable tannins and degradation of condensed tannin. Low molecular weight of condensed tannin of khalal date was $0.4936 \%$ which decreased to 0.4714 and $0.4072 \%$ of natural rutab and artificial rutab respectively. High molecular weight of condensed amhat tannin was $1.6544 \%$, This concentration decreased by ripening to 0.9100 and $0.6095 \%$ of natural rutab and artificial rutab respectively .The high decrease of artificial ripening resulting from the effect of heating on degradation of condensed tannins but natural ripening was affected by enzymatic hydrolysis only. From (Table 4) it was cleared that soluble and condensed tannins showed high significant difference than $\mathrm{N}$. rutab and $\mathrm{A}$. rutab.

So, The decreases of total phenolic compounds may be related to role of the browning reaction (enzymatic for natural amhat date and non enzymatic for artificial amhat date). Also a clear decreases in hydrolysable tannin of natural amhat than artificial amhat by enzymatic hydrolysis as reported by ( Tanaka et al., 1994 ) but condensed tannin ( LMW and HMW ) of natural rutab exhibited more decrease as showed in Table ( 4 ) these results coming from the effect of heating.

Table 4. Phenolic compounds of (mg / $100 \mathrm{~g}$ ) of khalal Amhat date, natural and artificial rutab Amhat date (on dry weight basis)

\begin{tabular}{lcccc}
\hline $\begin{array}{l}\text { Samples } \\
\text { Items }\end{array}$ & Khalal Amhat date & $\begin{array}{c}\text { Natural rutab } \\
\text { Amhat date }\end{array}$ & $\begin{array}{c}\text { Artificial rutab } \\
\text { Amhat date }\end{array}$ & LSD \\
\hline $\begin{array}{l}\text { Total phenolic } \\
\text { compound }\end{array}$ & $2.860 \pm 0.072^{\mathrm{a}}$ & $1.524 \pm 0.038^{\mathrm{c}}$ & $1.847 \pm 0.046^{\mathrm{b}}$ & $0.1076^{0.05}$ \\
$\quad \begin{array}{c}\text { Simple phenols } \\
\text { Hydrolysable tannin }\end{array}$ & $1.330 \pm 0.033^{\mathrm{a}}$ & $1.318 \pm 0.033^{\mathrm{a}}$ & $0.640 \pm 0.016^{\mathrm{b}}$ & $0.0571^{0.05}$ \\
$\quad \begin{array}{c}\text { Condensed tannin } \\
\quad \text { LMW }\end{array}$ & $2.1470 \pm 0.034^{\mathrm{a}}$ & $0.950 \pm 0.024^{\mathrm{c}}$ & $1.160 \pm 0.029^{\mathrm{b}}$ & $0.0586^{0.05}$ \\
$\quad$ & $0.4936 \pm 0.0024^{\mathrm{a}}$ & $1.39416 \pm 0.035^{\mathrm{b}}$ & $1.0767 \pm 0.027^{\mathrm{c}}$ & $0.080^{0.05}$ \\
$\quad$ HMW & $1.6544 \pm 0.0252^{\mathrm{a}}$ & $0.4714 \pm 0.0019^{\mathrm{b}}$ & $0.4072 \pm 0.0018^{\mathrm{c}}$ & $0.0039^{0.05}$ \\
\hline
\end{tabular}

The mean value with different superscript alphabets in rows indicate significantly differences $(\mathrm{p} \leq 0.05)$ using LSD TEST.

\section{The browning content on Amhat date.}

From Table ( 5 ) it is clear that the browning reaction is occurred in natural Amhat date more than artificial Amhat date because enzymatic effect by polyphenol oxidase had good role for change the color through browning reaction ( enzymatic browning ) but artificial Amhat date showed a less browning color non - enzymatic browning reaction between amino acids

( tyrosine, phenylalanine ) and sugars ( Nezam El Din and Abd El - Hameed., 1997 ) . 
Table 5. Browning content measured as optical density at $420 \mathrm{~nm}$ of amhat date .

\begin{tabular}{lc}
\hline Samples & Optical density $420 \mathrm{~nm}$ \\
\hline Amhat date ( khalal stage ) & $\mathbf{0 . 2 5 7}$ \\
Amhat date ( natural rutab ) & $\mathbf{0 . 7 9 2}$ \\
Amhat date ( artificial rutab ) & $\mathbf{0 . 7 1 4}$ \\
\hline
\end{tabular}

*The color measured as optical density per 1 gm dry matter.

\section{The antioxidant capacity of Amhat date}

From Table (6) it was found that total antioxidant capacity of khalal amhat date was $1297.119 \mathrm{mg} / 100$ $\mathrm{g}, 1293.877 \mathrm{mg} / 100 \mathrm{~g}$ and $372.9 \mathrm{mg} / 100 \mathrm{~g}$ for natural and artificial ripening of amhat dates .

So, the total antioxidant capacity very high in khalal date which composed of phenolic compounds , hydrolysable tannins ( gallo and ellagi tannins ) and condensed tannins ( low and high molecular weight tannins ).
So, A significant difference between khalal date and artificial ripening very high, also khalal date showed a high significant difference more than artificial ripening.

A high significant difference between natural ripening and artificial ripening. No significant difference between khalal date and natural ripening .

Poly phenolic compounds effect on antioxidant capacity related to their hydroxyl content of their aromatic ring which lead to chelate and scavenging the free radicals.( Dekok et al., 2008 )

Table 6. Total antioxidant capacity of amhat dates $(\mathrm{mg} / 100 \mathrm{~g})$ as ascorbic acid equivalent on fresh weigh basis .

\begin{tabular}{|c|c|c|c|c|}
\hline $\begin{array}{l}\text { Samples } \\
\text { Items }\end{array}$ & Khalal & $\begin{array}{c}\text { Natural } \\
\text { ripening rutab }\end{array}$ & $\begin{array}{c}\text { Artificial ripening } \\
\text { rutab }\end{array}$ & LSD \\
\hline $\begin{array}{c}\text { Total antioxidant } \\
\text { capacity }\end{array}$ & $\begin{array}{c}1297.119 \pm 64.856^{\mathrm{a}} \\
(\mathrm{mg} / 100 \mathrm{~g}) \text { as } \\
\text { ascorbic acid } \\
\text { equivalent }\end{array}$ & $\begin{array}{l}1293.877 \pm 64.694^{\mathrm{a}}( \\
\mathrm{mg} / 100 \mathrm{~g}) \text { as ascorbic } \\
\text { acid equivalent }\end{array}$ & $\begin{array}{c}372.9 \pm 18.645^{\mathrm{b}} \\
(\mathrm{mg} / 100 \mathrm{~g}) \text { as } \\
\text { ascorbic acid } \\
\text { equivalent }\end{array}$ & $107.83^{0.05}$ \\
\hline
\end{tabular}

* The mean value with different superscript alphabets in rows indicate significantly differences ( $\mathrm{p} \leq 0.05$ ) using LSD TEST

7. Fractionation of phenolic compounds content by HPLC (High Performance Liquid Chromatography ).

From Table (7) it was appeared that the maximum Phenolinc compounds of khalal dates were pyrogallol ( $122.344 \mathrm{mg} / 100 \mathrm{~g})$, Gallic acid ( $80.394 \mathrm{mg} / 100 \mathrm{~g}$ ), Catechol ( $10.276 \mathrm{mg} / 100 \mathrm{~g}$ ), Chlorgenic acid ( $30.147 \mathrm{mg} / 100 \mathrm{~g}$ ), Caffeic acid ( $25.289 \mathrm{mg} / 100 \mathrm{~g}$ ) Vanillin ( $2.033 \mathrm{mg} / 100 \mathrm{~g}$ ) and Ellagic acid

( $377.377 \mathrm{mg} / 100 \mathrm{~g}$ ). And the maximum phenolic compound of natural ripening ( rutab ) were $\mathrm{P}$ - hydroxy benzoic acid ( $24.421 \mathrm{mg} / 100 \mathrm{~g}$ ), Syringic acid ( $5.745 \mathrm{mg} / 100 \mathrm{~g}$ ), Caffeine $(51.865 \mathrm{mg} / 100 \mathrm{~g}$ ) P- Coumaric acid ( $2.074 \mathrm{mg} / 100 \mathrm{~g}$ ) Ferulic acid ( $5.259 \mathrm{mg} / 100 \mathrm{~g}$ ) and Salicylic acid (13.273 mg / $100 \mathrm{~g})$ and Cinnamic acid ( $5.180 \mathrm{mg} / 100 \mathrm{~g}$ ). The maximum phenolic compound of artificial ripening of Amhat dates were Quinol ( $68.798 \mathrm{mg} / 100 \mathrm{~g}$ ), Vanillic acid ( $17.787 \mathrm{mg} / 100 \mathrm{~g})$ and Benzoic acid ( $33.479 \mathrm{mg} / 100 \mathrm{~g}$ ). The important role of phenlic compounds is inhibition of cellular proliferation. (Kuntz et al., 1999)

Table 7. Fractionation of phenolic compounds content ( $\mathrm{mg} / 100 \mathrm{~g}$ on dry weight basis ) by HPLC (High Performance Liquid Chromatography ) of amhat date.

\begin{tabular}{|c|c|c|c|}
\hline $\begin{array}{l}\text { Samples } \\
\text { Items } \\
\end{array}$ & Khalal & Natural rutab & Artificial rutab \\
\hline Pyrogallol & 122.344 & 54.461 & ND \\
\hline Quinol & ND & ND & 68.798 \\
\hline Gallic acid & 80.394 & 10.504 & 0.927 \\
\hline Catechol & 10.276 & 7.460 & 1.551 \\
\hline P- hydroxy benzoic acid & 12.770 & 24.421 & 1.769 \\
\hline Caffeine & ND & 51.865 & 2.289 \\
\hline Chlorogenic acid & 30.147 & 4.750 & 0.466 \\
\hline Vanillic acid & ND & 1.769 & 17.787 \\
\hline Caffeic acid & 25.289 & 2.154 & 0.660 \\
\hline Syringic acid & 3.712 & 5.745 & 0.454 \\
\hline Vanillin & 2.033 & 1.885 & 0.561 \\
\hline P-coumaric acid & 0.565 & 2.074 & 0.876 \\
\hline Ferulic acid & ND & 5.259 & 0.584 \\
\hline Benzoic acid & ND & ND & 33.479 \\
\hline Ellagic acid & 377.377 & ND & 14.198 \\
\hline O- coumaric acid & ND & ND & 0.456 \\
\hline Salicylic acid & 6.077 & 13.273 & 0.204 \\
\hline Cinnamic acid & 3.829 & 5.180 & 0.743 \\
\hline
\end{tabular}

*ND: Not Detected 
8. Fractionation of flavonoid compounds content by HPLC (High Performance Liquid Chromatography)

The maximum flavonoids of khalal dates were Myricetin ( $488.636 \mathrm{mg} / 100 \mathrm{~g}$ ) and Rutin $(42.409 \mathrm{mg} / 100 \mathrm{~g})$ and for natural rutab dates were

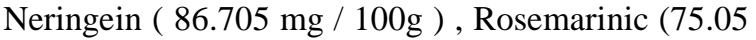
$\mathrm{mg} / 100 \mathrm{~g}$ ), Myricetin ( $47.480 \mathrm{mg} / 100 \mathrm{~g}$ ) and Kampherol ( $27.705 \mathrm{mg} / 100 \mathrm{~g}$ ) but artificial ripening rutab contained only Myricetin ( $20.357 \mathrm{mg}$ / 100g ) and Rutin (7.888 mg / $100 \mathrm{~g}$ ) which were less than the others . (Table 8)

Table 8. Fractionation of flavonoid compounds content (mg / $100 \mathrm{~g}$ ) on dry weight basis by HPLC (High Performance Liquid Chromatography ) .

\begin{tabular}{|c|c|c|c|}
\hline $\begin{array}{l}\text { Samples } \\
\text { Items }\end{array}$ & Khalal & Natural rutab & Artificial rutab \\
\hline Myricetin & 488.636 & 47.480 & 20.357 \\
\hline Quercitin & ND & 7.187 & ND \\
\hline Rosemarinic & ND & 75.050 & ND \\
\hline Neringein & ND & 86.911 & ND \\
\hline Kampherol & ND & 27.705 & ND \\
\hline Rutin & 42.409 & 36.413 & 7.888 \\
\hline
\end{tabular}

*ND: Not Detected

( Quercitin , rutin and myricetin ) and cumaric, gallic, ellagic, ferulic and hydrolysable tannins) prevent cancer and inflammatory disease. A positive correlation between polyphenolic content and cancer reduction. (Carocho and Ferreira.2013).

\section{Biological Evaluation}

\section{Cytotoxic effect as anticancer}

By measuring the effect of Amhat date extracts on human liver carcinoma cell line ( HEPG 2 ) for studying in vitro its effect as cytotoxic ( Table 9 and 10) (Figure 1 and 2 ), it was found that using some solvents ( methanol $100 \%$, methanol $75 \%$ and acetone $70 \%$ ) to extract khalal, natural rutab and artificial rutab exhibited lower $\mathrm{IC}_{50}$ (concentration lead to decrease cell viability to $50 \%$ ) Than ethanol .

These results revealed that methanol $100 \%$ extracted saponin, methanol $75 \%$ extracted total phenolic compounds ( Yuliana et al.,2014 ) and acetone $70 \%$ extracted total tannin ( Makkar, 2003).

So, the best $\mathrm{IC}_{50}$ was natural rutab which led to the lowest $\mathrm{IC}_{50}(153 \mu \mathrm{g} / \mathrm{ml})$ for inhibition of the liver carcinoma cell line (HEPG 2).

Table 9. Cytotoxic effect of Amhat dates fruit against human liver cancer cell lines (HEPG2) extraction by ethanol $70 \%$.

\begin{tabular}{lccccccc}
\hline Solvent & Samples & $\mathbf{0}$ & $\mathbf{6 2 . 5}$ & $\mathbf{1 2 5}$ & $\mathbf{2 5 0}$ & $\mathbf{5 0 0}$ & IC $_{\mathbf{5 0}}$ \\
\hline \multirow{2}{*}{ Khalal } & 100.0 & 77.0 & 65.0 & 50.0 & 45.1 & 250 \\
& & & & & & & \\
& N. Rutab & 100.0 & 62.2 & 60.9 & 59.5 & 45.4 & 157 \\
\hline
\end{tabular}

$\mathrm{IC}_{50}$ : Concentration able to decrease cell viability by $50 \%$ versus control culture.

Table 10. Cytotoxic effect of Amhat dates fruit against human liver cancer cell lines (HEPG2) extraction by methanol $100 \%$, methanol $75 \%$ and acetone $70 \%$.

\begin{tabular}{|c|c|c|c|c|c|c|c|}
\hline \multirow{2}{*}{ Solvent } & \multirow{2}{*}{ Samples } & \multicolumn{5}{|c|}{ Concentration $\mu \mathrm{g} / \mathrm{ml}$} & \multirow{2}{*}{ IC $_{50}$} \\
\hline & & $\mathbf{0}$ & 62.5 & 125 & 250 & 500 & \\
\hline \multirow{3}{*}{ 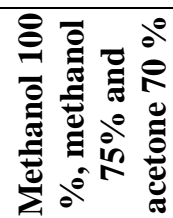 } & Khalal & 100.0 & 71.1 & 67.0 & 55.4 & 58.6 & 230 \\
\hline & N. Rutab & 100.0 & 66.4 & 55.4 & 41.1 & 39.0 & 153 \\
\hline & A.Rutab & 100.0 & 93.3 & 74.5 & 39.9 & 44.6 & 207 \\
\hline
\end{tabular}

$\mathrm{IC}_{50}$ : Concentration able to decrease cell viability by $50 \%$ versus control culture.

Also, Table (7) illustrated that Syringic acid, PQumaric acid, Ferulic acid,Salicylic acid and Cinnamic acid represented the maximum concentration for natural rutab which may by one and for more are the responsible phenolic compounds for inhibition effect for liver carcinoma cell line . And from flavonoids one and more (Quercitin , Rosemarinic , Neringein , Myricetin and 
Kampherol) are responsible for inhibition of cancer cells. (Bawadi et al , 2005 ; Ramos, 2008 ; Wang et al , 2013 ; and Subramanin et al, 2016 )

The lowest $\mathrm{IC}_{50}$ ( extracted by ethanol and some solvents ) was found for natural rutab which represent $(157 \mu \mathrm{g} / \mathrm{ml})$ and $(153 \mu \mathrm{g} / \mathrm{ml})$ respectively, this meaning that natural ruab is better than the others to inhibition the liver cancer cell ( HEPG 2).
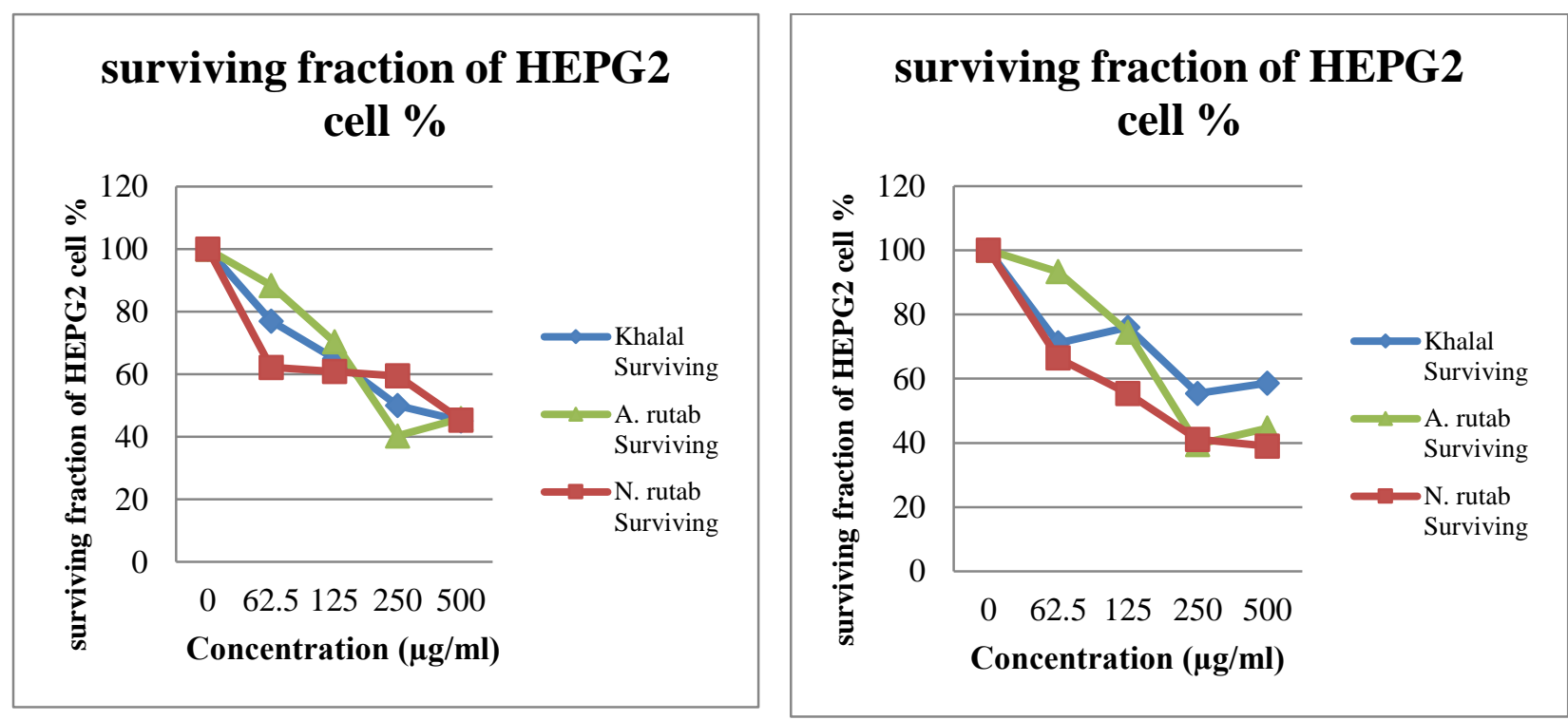

Figure (1): Cytotoxic effect of Amhat dates fruit against human liver cancer cell lines ( HEPG2 ) extraction by ethanol $70 \%$.

figure(2): Cytotoxic effect of Amhat date against human liver cancer cell extraction bymethanol $100 \%$, methanol $75 \%$ and acetone $70 \%$

The responsible change of every compounds of anticancer: By comparing the phenolic compounds ( Table 7 ) to the $\mathrm{IC}_{50}$ of Amhat date ( Khalal, Natural and artificial ripening ) it appeared that one or more of these phenolic compounds (caffeine, p-coumaric acid and ferulic acid ) are responsible for enhancing $\mathrm{IC}_{50}$ and act as anticancer agent .( Alias et al., 2009 ).

Coumaric group have antitumor activity to certain extent this group such as coumarin , 4hydroxy coumarin , 7-hydroxycoumarin, dicoumarin , psoralidin, warfarin, dephetin and coumarin aesculetin. These compounds have been studied for anticancer properties . coumarin and its derivatives have activity against human pancreatic . (Devji $\boldsymbol{e t}$ al.,2011). SO, it is may be have a synergetic effects of some phenolic compounds on $\mathrm{IC}_{50}$ of Amhat date to have clear effects more than one phenolic compound alone.

10. Microbiological Evaluation Effect of Amhat date extracts as antimicrobial agents.

From Table ( 11 ), it was found that the extract of Khalal Amhat date did not exhibited any effect on all micro - organisms by using concentration $100 \mu 1$ but the concentration $200 \mu \mathrm{l}$ had positive effects on E. coli and Salmonella typhi with growth inhibition reached to $2.7 \mathrm{~cm}$ and $3.0 \mathrm{~cm}$ respectively .

Also, the concentration $400 \mu \mathrm{l}$ led to more inhibition of micro - organisms growth which reached to $3.0,3.7$ and $2.0 \mathrm{~cm}$ for E. coli, Salmonella typhi and Staphylococcus aureus respectively but no effect appeared for the others .
Natural Rutab date extract with concentration 100 $\mu l$ had positive effect only with Salmonella typhi and its inhibition growth of diameter reached to $2.8 \mathrm{~cm}$ but the double concentration ( $200 \mu \mathrm{l}$ ) led to positive effect on E. coli, Salmonella typhi and Staphylococcus aureus and inhibition effects reached to $3,3.5$ and $2.1 \mathrm{~cm}$ respectively, also the maximum concentration ( $400 \mu \mathrm{l}$ ) exhibited high inhibition effects on E. coli, Salmonella typhi and Staphylococcus aureus which reached to 4,4 and 2.3 cm respectively .(Saleh et al.,2013)

Artificial ripening of amhat date ( A. Rutab ) extract with concentration $100 \mu \mathrm{l}$ had positive effect on E. coli and Salmonella typhi and the inhibition of previous micro - organisms reached to 3.3 and 3.2 $\mathrm{cm}$ respectively. But the other micro - organisms did not exhibited any inhibition as showen .

In Table (11) By measuring the concentration of artificial rutab extract to be 200 and $400 \mu 1$ led to increase the effect of inhibition of $E$. coli from 3.4 to $4.0 \mathrm{~cm}$ respectively and inhibition Salmonella typhi from 3.3 to $4.0 \mathrm{~cm}$ respectively .

It is clear from Table (11) that the significant difference increase by increasing the concentration from $100 \mu \mathrm{l}$ to $200 \mu \mathrm{l}$ to $400 \mu \mathrm{l}$ as shown for E. coli, Salmonella typhi and Staph.(Qadoos et al.,2017).

The strongest effect of A. rutab extract on E. coli may be related to $A$. rutab extract contain more amounts of vanillic acid than these found in N. rutab date. ( Naz et al.,2006). 
Table 11. The antimicrobial effect of amhat date extracts (Zone diameter of inhibition,cm)

\begin{tabular}{|c|c|c|c|c|c|c|}
\hline Samples & Conc. & $\begin{array}{c}E . \text { coli } \\
\text { ATCC25922 }\end{array}$ & $\begin{array}{c}\text { Salmonella } \\
\text { ATCC19930 }\end{array}$ & $\begin{array}{c}\text { Staph. } \\
\text { aureus. } \\
\text { MRSA } \\
\text { ATCC43300 } \\
\end{array}$ & $\begin{array}{c}\text { B. subtilis } \\
\text { ATCC6051 }\end{array}$ & $\begin{array}{c}\text { Asperigillus flavus } \\
\text { CAICC41 }\end{array}$ \\
\hline \multirow{2}{*}{ Khalal } & $100 \mu \mathrm{l}$ & NO & NO & NO & $\mathrm{NO}$ & NO \\
\hline & $\begin{array}{l}200 \mu l \\
400 \mu l\end{array}$ & $\begin{array}{c}2.7 \pm 0.068^{\mathrm{b}} \\
3 \pm 0.075^{\mathrm{a}} \\
\mathbf{0 . 1 1 6}^{\mathbf{0 . 0 5}}\end{array}$ & $\begin{array}{c}3 \pm 0.075^{\mathrm{b}} \\
3.7 \pm 0.093^{\mathrm{a}} \\
\mathbf{0 . 1 3 8}^{\mathbf{0 . 0 5}}\end{array}$ & $\begin{array}{c}\text { NO } \\
2 \pm 0.050^{\mathrm{a}} \\
\mathbf{0 . 0 5 8}^{\mathbf{0 . 0 5}}\end{array}$ & $\begin{array}{l}\mathrm{NO} \\
\mathrm{NO}\end{array}$ & $\begin{array}{l}\mathrm{NO} \\
\mathrm{NO}\end{array}$ \\
\hline LSD & $100 \mu \mathrm{l}$ & NO & $2.8 \pm 0.070^{c}$ & NO & NO & NO \\
\hline N. Rutab & $\begin{array}{l}200 \mu l \\
400 \mu l\end{array}$ & $\begin{array}{c}3 \pm 0.075^{\mathrm{b}} \\
4 \pm 0.10^{\mathrm{a}}\end{array}$ & $\begin{array}{c}3.5 \pm 0.088^{\mathrm{b}} \\
4 \pm 0.10^{\mathrm{a}}\end{array}$ & $\begin{array}{l}2.1 \pm 0.053^{\mathrm{b}} \\
2.3 \pm 0.058^{\mathrm{a}}\end{array}$ & $\begin{array}{l}\text { NO } \\
\text { NO }\end{array}$ & $\begin{array}{l}\mathrm{NO} \\
\mathrm{NO}\end{array}$ \\
\hline LSD & & $\begin{array}{c}\mathbf{0 . 1 4 4 ^ { \mathbf { 0 . 0 5 } }} \\
3.3 \pm 0.083^{\mathrm{c}}\end{array}$ & $\begin{array}{c}\mathbf{0 . 1 7 3}^{\mathbf{0 . 0 5}} \\
3.2+0.080^{\mathrm{c}}\end{array}$ & $\begin{array}{c}\mathbf{0 . 0 9 0}^{\mathbf{0 . 0 5}} \\
\text { NO }\end{array}$ & NO & NO \\
\hline \multirow{2}{*}{ A. Rutab } & $200 \mu l$ & $3.4 \pm 0.085^{b}$ & & NO & NO & NO \\
\hline & $400 \mu \mathrm{l}$ & $4 \pm 0.10^{\mathrm{a}}$ & $4 \pm 0.10^{\mathrm{a}}$ & NO & NO & NO \\
\hline LSD & & $0.179^{0.05}$ & $0.176^{0.05}$ & - & - & - \\
\hline
\end{tabular}

*NO : Not Observed * each $100 \mu$ l contain of $0.125 \mathrm{mg}$ of samples extract $*$ The mean value with different superscript alphabets in rows indicate significantly differences $(\mathrm{p} \leq 0.05)$ using LSD TEST

\section{Sensory Evaluation}

The organoleptic evaluation (Table 12) illustrated that no significant difference between natural and artificial ripening as shown in color, this result may be related to small difference in browning content of natural and artificial rutab ( Table 5 ) also, no significant difference between natural and artificial ripening as shown in general appearance but a significant difference in taste, odor and texture . Significant difference in texture may be related to the inhibition of pectinase enzyme ( enzyme responsible for smooth ) as effect of heat used to obtain artificial rutab . ( Pedrolli et al., 2009). In general, artificial rutab amhat dates are sensually acceptable.

Table 12. Sensory evaluation of Natural and Artificial ripening amhat date

\begin{tabular}{lccc}
\hline Test & Samples & Values & LSD \\
\hline \multirow{2}{*}{ Color } & Natural ripening & $9.40 \pm 0.737^{\mathrm{a}}$ & $0.824^{0.05}$ \\
& Artificial ripening & $8.80 \pm 1.373^{\mathrm{a}}$ & $0.653^{0.05}$ \\
Taste & Natural ripening & $10.00 \pm 0.00^{\mathrm{a}}$ & \\
& Artificial ripening & $8.33 \pm 1.234^{\mathrm{b}}$ & $0.326^{0.05}$ \\
Odor & Natural ripening & $10.00 \pm 0.00^{\mathrm{a}}$ & $0.339^{0.05}$ \\
& Artificial ripening & $9.67 \pm 0.617^{\mathrm{b}}$ & \multirow{2}{*}{ Texture } \\
& Natural ripening & $10.00 \pm 0.00^{\mathrm{a}}$ & $0.500^{0.05}$ \\
\hline
\end{tabular}

* The mean value with different superscript alphabets in rows indicate significantly differences $(\mathrm{p} \leq 0.05)$ using LSD TEST

\section{Conclusion:}

Amhat date palm is rich by sugers, minerals, fiber and bioactive component ( phenolic compounds and tannins ) in high levels. Date palm plays a good role as antioxidant, anticancer and antimicrobial agent, therefore recommended consumption in all stages.

\section{References}

A.A.C.S. (2016).Administration Center of Agriculture Economics and Statistics, Ministry of Agriculture, Egypt.
Abo Taleb, H.M. ; Abd El-Aziz, H.A. and Abd ElHameed, A.K. (2017). Novel Products from Amhate Date. J. of Food Science, Suez Canal University.Vol.5 (1): 1-10.

Adeosun, A.M. ; Oni, S. O. ; Ighodaro, O. M. ; Durosinlorn, O. H. and Oyedele, O. M. (2016). Pytochemical, minerals and free radical Scavenging profiles of Phoenix dactylifera L. seed extracts. Journal of Taibah Univ. Medical Sci., 11 (1) : 1-6 .

Al- Hooti, s. ; Sidhu, J. S. and Qabazard, H. (1997) Pytochemical Characteristics of five date 
fruit cultivars grown in the United Arab Emirates. Plant Foods for Human Nutrition 50 :101-113.

Alias, L.M. ; Manoharam, S. ; Vellaichammy, L. and Balakrishnan, S.(2009). Protective effect of ferulic acid on 7,12- dimethybenz (a) Anthracen- induced skin carcinogenesis in Swiss albino mice. Exp. Toxical Pathol. ,61:205-214.

AOAC (2016). Association of Official Analytical Chemists international Official Methods of Analysis $20^{\text {th }} \mathrm{ed}$. Washington,DC,USA .

Barrett, D. M. ; Beaulien, J. C. and Shewefelt, R. ( 2010).Color , flavor, Texture , and Nutrition Quality of fresh cut fruit and vegetable : Desirable levels. Instrumental and Sensory measurement, and the effects of processing . Critical Reviews in Food Science and Nutrition, $50: 369-389$.

Bawadi, H. A. ; Trappey, A. and Losso, J. N. (2005). Inhibition of Caco-2- Colon MCF7 and HS5778 T breast and DU145 prostatic cancer cell Proliferation by water soluble black bean condensed tannins. Cancer let. , (2) :153-162.

Benmeddour, Z. ; Mehinagic, E. and Meurlay, D. ( 2012 ). Phenolic composition and antioxidant capacity of ten Algerian date Phoenix dactylifera L. cultivars :A Comparative Study, J. of Functional Food, 11-005.

Carocho, M. and Ferreira, I.C.E. (2013). The role of phenolic compounds in the fight against cancer $-\mathrm{A}$ review Anticancer Agent in medicinal chemistry. $13: 1236-1258$.

Chinnici, F,;U. Spinabelli ; C. Riponi and Amati, A. (2005). Optimiztion of determination of organic acids and sugars in fruit juice by ionexclusive liquids chromatography . Journal of Food Composition and Analysis . 18:121:130.

Czochanska,Z. ;Foo, L.Y. and Porter, L.J. (1979) . Compositional changes in lower molecular weight flavans during Maturalion phytochemistry, 18:1819.

Daoud, A., Malika, D. and Gharsallah , N. (2015). Assessment of Polyphenol Composition , Antioxidant and antimicrobial properties of various extracts of Date palm pollen (PPP) from two Tunisian cultivars Arabian . J. of chem. 12:3075-3086.

Dekok, I.M. ; Vanbreda, S. G. ; Manson, M.M. (2008). Mechanisms of Combined action of diffedrent chemo-preventive dietary Compounds, Areview . Eur. J. Nutr., 9 : 47-51.

Devji, T. ; Reddy, C. ; Woo, C. ; Awale, S. ; Kadofa, S. and Carrico- Monitz,D.(2011). Pancreatic anticancer activity of a novel geranylated coumarin derivative. Bio-organic \& Medicinal Chemistry Letters . (21): 5770-5773.

Du,c.; Zhang ; wen,X,; Yu,c.; Calway,T. , Yuan, c. and wang.c. (2012) Epigallo catchin (EGCG) the most effective cancer chemo-Preventive polyphenols in green tea. Nutrients,4:16791691.

Fadda , A.A. and Hala , M.R. (2013). Synthesis and antimicrobial activity of some novel hydrazide , benzochromenone, dihydropyridine, ,pyrrole , thiazole and thiophene derivatives-Euro.J. of Med. Chem ; 70:419-426.

FAO.(2016) Food and Agriculture organization online citation: http:// Qwww.fao.prg/faostat/en/£data/QC.\# /data/OC.

Iqbal, Z. ; Sajid, M. S. ; Abbas, R. Z. and Sindhu, Z. U. (2011). Determination of condensed tannin content from different plants of Kherimurat Rangeland ( Attock, Pakistan ). Journal of Agric. and Social Science , 7:114116.

Khan, F.; Kumosani, T. and Abuzenadah,A. (2016) . Ajwa date (Phoenix dactyliferal) extract inhibits human breast Adenocarcinoma (MCF7) in vitro by inducing Apoptosis and cell cycle Arrest. Plos One 11(7). Doi:10.1371/ J. pone. 0158963 .

Kuntz, S. Wenzel, U. and Daniel, H. (1999). Comparative analysis of the Effects of flavonoids on proliferation, cytotoxic and apoptosis in Human colon cancer cell line. Eur. J. Nutri., 38:133-142.

Makkar , H.P.S. (2003). Quantification of tannins in tree and Shrub foliage : Laboratory manual. Kluwer academic publishers, Dordrecht, the Netherlands.FAO / IAEA Working Document IAEA, Vienna.

Nasir, M. U. ; Hussain, S. ; Jabbar, S. ; Rashid, F. ; Khalid, N. and Mehmood, A. (2014).A review on the nutritional content, functional properties and medicinal potential of dates . Sci. Lett. 3 (1):1-6 Issue 1 online first 2014044SL.

Naskar, S, ; Saha, P. and Haldar, P. K. (2010 ). In vito and in vivo antioxidant potential of hydromethanolic extract of Phoenix dactylifera L. fruit . J. of Sci. Res. ; 2(1):144-157.

Naz, S. ; Ahmed, S. ; Rasool, S. A. ; Sayeed, S. A. and Siddiq, R. (2006). Antimicrobial activity directed isolation of compounds from Onosma hispidum. Microbial Research 161:43-48.

Nezam El-Din , A. M. M. and Abd El- Hameed, A. K. (2003). Production of Khalal date powder proceeding of international Conference on date palm . Kingdom of Saudi Arabia . Ministry of Higher Education . King Saud Univ. Qaseem Branch - College of Agric. And Vet . Med . 16-19 Sep. ,87-101.

Nezam El-Din , A. M. M. and Abd El- Hameed, A. K. (1997). Chemical and technological study on Egyptian Amhate date .Effect of temperature on ripening of Khalal date. Egypt J. Agric. Res. ,75 (4):1113- 1121. 
Orahan, D. ; Ozgen, S. and Ergan, F. (2009). Antibacterial , antifungal, and antiviral activities of some flavonoids . Microbiological Research . Bioscience ; $61:$ 632-638.

Parr, A. J. and Bolwell, G. P. (2000). Phenols in the plant and in man. The potential for possible nutritional enhancement of the diet by Modifying the phenols content or profile . J. Sci. Food Agric. ; 80:985-1012.

Pedrolli, D. B. ; Monteiro, A. C. ; Gomes, E. and Carmona.(2009). Pectin and Pectinase: Production, Characterization and Industrial Application of Microbial Pectinolytic Enzymes . The Open Biotechnology Journal, 3:9-18.

Pirjo, M. A. J. and Jorma, K. (2000). Determination of flavonoids in plant Material by HPLC with diode - array and electro- array detections. Journal of Agric. And Food Chemistry, 48-5834-5841.

Qadoos, H.A. ; Dhafari, H.S. ; Al-Marzooqi, D.A. ;Yaqoubi, A. I. ; Kumarappan, a. ; Nazir, A. and Elsori, D.H. (2017).Phenolic content and antimicrobial activities of date palm ( Phoenix dactylifera L. ) fruit and leaves. Food Biology 6:11-15 .

Ramose, S.(2008). Cancer Chemoprevention and Chemotherapy, dietry Polyphenols and Signalling Pathway. Journal of Mol. Nutri. Food Res. (52):507-526.

Ranganna, S. (2007). Habdbook of analysis and quality control for fruit and vegetables product . $2^{\text {nd }}$ Ed. New Delhi, Indian.

Rebaya, A. ; Belghith, S.I. ; Baghdikian, B. ; Leddet, V. M. ; Mabrouki, F. ; Olivier, E. ; Cherif, J. K. and Ayadi, M. T. (2014). Total phenolic, total flavonoids, tannin content and antioxidant capacity of Halimium halimifolium (Cistaceae ) .Journal of Applied P/harmaceutical Sci., Vol. 5 (01),52-57.

Saleh, F.A. and Otaibi, M.M. (2013). Antibacterial activity of date palm Fruit at different ripening stages. J. of Food process Technol.; 4 (12): 1-6
Seeram, N.L. ; Adoms, L.S., Hennings, S. M. ; Niu, Y.; Zhang Y.; Nair, M. G. and Heber, D. (2005). In vitro antiproliferatic, apoptotic and Antioxidant activity of punicalagm, ellagic acid and total pomegranate tannin extract enhanced in combination with other polyphenols as found in pomegranate juice. Journal of Nutritional Biochemistry . $16: 360$ 367.

Skehan, P.; Stroreng, R.; Scudiero , D. and Vistica, D. (1990). New Colorimetric cytotoxicity assay for anticancer drug screening J. of Natl. cancer Inst.; 82(13): 1107-1112

Stratil, P. ; Klejdus, B. and Kuban, V. (2006). Determination of Total Content of Phenolic Compounds and Their Antioxidant Activity in Vegetable-Evaluation of Spectrophotometric Methods . J. Agric. Food Chem.,59:607-616,

Subramanian, A. P.; Jaganathan, S. K. and Muhamad I.I. (2016) . Gallic acid induced apoptotic events in HCT-15 colon cancer cells. World J. of Gastroenterology; 22(15): 39523961 .

Tanaka, T.; Takahashi, R. ; Kouno, I. and Nonaka, G. (1994). Chemical Evidence for the de-astringency (insolubilization of tannins) of Persimmon fruit . J . Chem. Soci- perkin Tans 1 : 3013-3022

Wang, G. ; Song, L. ;Wang, H. and Xing, N. (2013). Quercetin synergizes With 2methoxyestradiol inhibiting cell growth and inducing apoptosis in human prostate cancer cells. J. of Oncol. Rep.; 30: 357-363.

Xu, B. J. and Chang, S. K. C. (2007). A comparative study on phenolic profiles and antioxidant activities of legumes as affected by extraction solvents. Journal of Food Science 72, S159-S166.

Yuliana, P. ; Laconi, E. B. ; Wina, E. and Jayanegara, A. (2014). Extraction of tannins and saponin from plant sources and their effect on in vitro methanogensis and rumen fermentation . J. Indonesian Trop. Anim. Agric. 39 (2):91-97. 


\section{التقييم الغذائي و النشاط المضاد للأكسدة و المضاد للسرطان و الميكروبات لصنف البلح الامهات المصري}

حسن حسن علي خلف* , رؤوف محمد عبد الله السعدني* , عبد الدحسن محمود محمود نظام الدين** يثرب عبد الستار احمد سالم***.

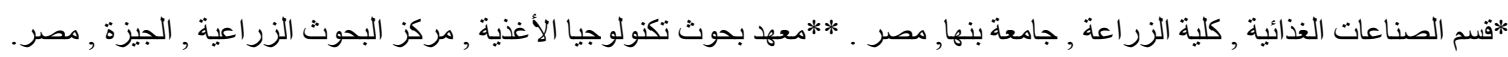

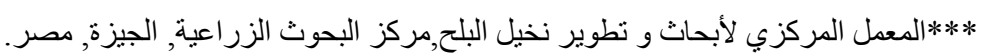

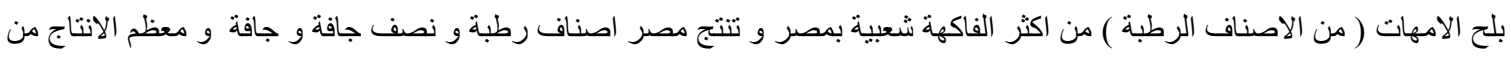
الاصناف الرطبة و لذلك كان من الضروري ترطيب البلح الامهات صناعيا للإطالة فترة صلاحيته و منع ظهور طعم غير مقبول به و عليه تم تقير التركيب الكيميائي للبلح الامهات ( الرطوبةـ المواد الصلبة الذائبة - البروتين - الدهون - الالياف الخام) و ايضا تم تقدير بعض العائ العناصر

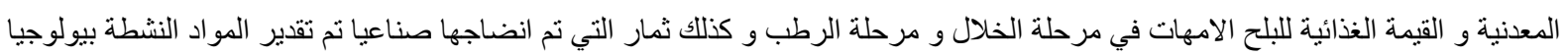

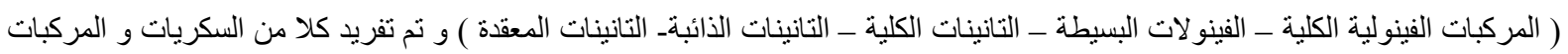

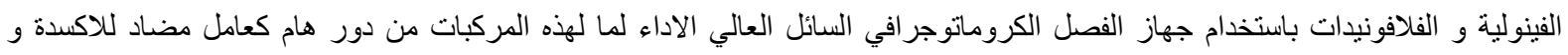

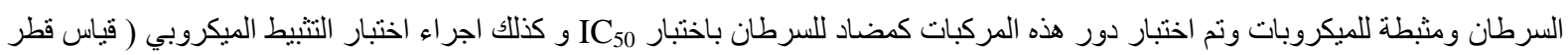

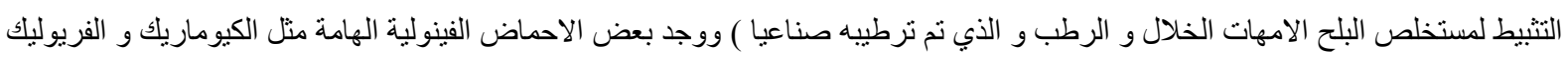
و الكافيين و التي قد يكون لها تأثير - منفردة او مجتمعة - كمضاد للسرطان و مثبط لنمو الاحياء الدقيقة. 